\title{
Sleep quality among residents of an old folk's home in Malaysia
}

\author{
Abdul Rashid, Eng Keat Ong, Eleanor Shu Yi Wong
}

\begin{abstract}
Background: Sleep is an essential part of life. Lack of sleep has been linked with increased morbidity and mortality. The objective of this study was to determine the sleep quality of older adults residing in a private elderly care institution in Malaysia.

Materials and Methods: This cross sectional study was conducted among consenting residents of a 200-bed non-governmental charity old folks home in Penang, Malaysia. The sleep quality of the respondents was measured using the Pittsburgh Sleep Quality Index (PSQI). Quality of life (WHOQOL-BREF), their attitude to ageing (AAQ), Barthel index (Activities of Daily Living) and body mass index were also measured. Data was analysed using PASW.

Results: The PSQI score ranged from 0 to 16 with a mean score of 7.1 (SD 3.4) and $76.8 \%$ (116) had scores $\geq 5$. The differences in the mean score for chronic illness $(t=0.14 / P=0.04)$, the people that could be counted on for help $(t=4.09 / P=0.02)$ and the feasibility of getting practical help from fellow residents $(t=4.41 / P=0.01)$ were statistically significant. There was a negative correlation between the PSQI score and the WHOQOL-BREF score (-0.318/0.00) and AAQ score (-0.332/0.00).

Conclusions: Staff working in an elderly care institution should understand the important relationship of illnesses, social support and sleep hygiene in the wellbeing of the residents.
\end{abstract}

Key words: Aged, home for the aged, Malaysia, sleep

\section{INTRODUCTION}

$\mathrm{M}$ ost countries across the continents are experiencing an ageing population phenomenon. It is projected that the population of older adults in the world will quadruple and that the elderly population in the developing countries will increase to almost two billion. ${ }^{[1]}$ The population of Malaysia is 25 million and is made up of several ethnic groups, comprising mostly of Malays and other indigenous groups followed by the Chinese, Indian and non-Malaysian citizens who mainly comprise of immigrant labourers. Malaysia's elderly population was $2.3 \%$ of the total population in 1997, in the year 2000 this proportion increased to $6.2 \%$ and it is projected that the elderly population of Malaysia will increase to $9.5 \%$ of the population in the year 2020. ${ }^{[2]}$ At present the population of the elderly in Malaysia is approximately two million. This increase can be attributed to improved health, longer life expectancy, low mortality as well as declining fertility. ${ }^{[3]}$ There has been a change in the family structure from the

Department of Public Health Medicine, Penang Medical College, 4 Jalan Sepoy Lines, 10450 Georgetown, Pulau Pinang, Malaysia

Address for Correspondence: Assoc. Prof. Dr. Abdul Rashid, Department of Public Health Medicine, Penang Medical College, 4 Jalan Sepoy Lines, 10450 Georgetown, Pulau Pinang, Malaysia. E-mail: drrashid10@gmail.com traditional extended families into nuclear families. Due to loss of spouse and inability to care for self, there has been an increase in the admissions of the elderly into institutional care facilities. This pattern of living arrangement has caused social implications for the older adults.

Sleep is an essential part of life. There are two types of sleep; non rapid eye movement (NREM) and rapid eye movement (REM) ${ }^{[3]}$ The restoration and repair of body tissue and the normal functioning of endocrine and immune system is influenced by sleep. Sleep quality of an individual encompasses sleep duration, sleep latency, depth of sleep and restfulness. ${ }^{[4]} \mathrm{A}$ good quality of sleep which is usually associated with fewer sleep disturbances helps to maintain mood, memory and cognitive performance. ${ }^{[5]}$ Lack of sleep has been linked with irritability and emotional distress, compromised endocrine and immune function, cognitive impairment, hypertension, impaired healing and obesity. ${ }^{[5-7]}$

Older adults generally require only 5 to 6 hours of sleep per night and due to the change in the circadian rhythm they tend to awaken early. ${ }^{[3]}$ Studies have shown that older adults take longer time to sleep, may awaken more frequently during the night and have greater difficulty getting back to sleep and sleep is shorter and periods of rapid eye movement are also infrequent and apnoeic episodes are common. . $^{[3,8]}$ 
Insomnia affects up to $30 \%$ of adult population affecting more women than men. ${ }^{[9,10]}$ In the United States of America (USA) the economic effects of insomnia has been estimated to range from US\$ 92 to 107 billion. ${ }^{[11]}$ Factors affecting sleep include inactive lifestyles, poor sleep practices, anxiety, depression, pain, discomfort, urgency, frequency and nocturia, restless legs, cramps, nocturnal cough or breathlessness, certain drugs and drug withdrawal. ${ }^{[8]}$

Majority of older adults with sleep disturbances do not seek help probably due to lack of knowledge about insomnia and due to under recognition and under diagnosis by health care personnel. ${ }^{[12]}$

Early detection and intervention of sleep disturbances among older adults can help reduce the morbidity and mortality associated with this and helps increase their quality of life. The objective of this study was to determine the sleep quality of older adults residing in a private elderly care residential institution in Penang Malaysia.

\section{Materials and Methods}

This cross sectional study was conducted in a 200-bed non-governmental charity elderly care residential institution in Penang, Malaysia from May to November 2011. The eligibility of being admitted into this institution includes those aged 60 and above, has no person to care for them, homeless or lacking funds for self-care. Participants were taken from among the residents of this institution. A purposive convenience sampling method was employed. Only residents who consented and were not debilitated with an illness which rendered them unable to communicate effectively were recruited into this study. The data was collected by the researchers using a questionnaire especially designed for this study. Besides the baseline demographic information the sleep quality of the respondents was measured using the Pittsburgh Sleep Quality Index (PSQI). PSQI is a reliable tool consisting of seven components including (a) subjective sleep quality (1 item) - overall sleep quality (b) sleep latency (2 items) - time spent trying to fall asleep each night (c) sleep duration (1 item) - hours of actual sleep each night (d) habitual sleep efficiency (2 items) - number of hours slept divided by the number of hours spent in bed multiplied by 100 (e) sleep disturbances (9 items) - frequency of trouble sleeping caused by certain events (f) use of sleep medication (1 Item) - frequency of taking medicine to help sleeping and ( $\mathrm{g}$ ) day time dysfunction ( 2 items) - difficulties to stay awake while doing daily activities. Each component is rated on a likert scale ranging from ' $0-3$ '. ' 0 ' represents the absence of any disorder and 3 represent maximum disorder. The sum of the scores range from $0-21$, a higher score suggests poorer sleep quality. A score of 5 and above on the PSQI total score indicate worse sleep quality. PSQI has a sensitivity of $89.6 \%$ and specificity of $86.5 \% .{ }^{[4]}$ In addition to PSQI, the quality of life of the respondents was measured using WHOQOL-BREF. This scale has four domains including physical, psychological, social and environment. Higher scores suggest higher quality of life. ${ }^{[13]}$ The participant's attitude to ageing was measured using Attitude to Ageing Questionnaire (AAQ). The scale has three domains which include psychological growth, psychosocial loss and physical change. Higher total scores for the psychosocial loss component indicate a negative attitude to ageing whereas higher total scores for the physical change and psychological growth components indicate a positive attitude to ageing. The scores for the psychosocial loss domain were reversed in order to be in line with the other domains where a higher score reflects a more positive attitude to ageing. The total score on the AAQ was used to give an indication of attitude to ageing. Higher total scores of the three domains indicate a positive attitude to ageing. ${ }^{[14]}$ Barthel index which is a well-established and commonly used nursing tool was used to assess the functional independence in the activities of daily living (ADL) of the participants. Body mass index which is used to accurately determine a person's nutritional status was also calculated. Data was be tabulated, cross tabulated and analysed using PASW version 18. Inferential analysis was done using $t$ tests. Regression analysis was attempted to determine the predictive risk factors. A probability value of $P<0.05$ was considered to be statistically significant. All respondents were asked to give an informed written consent before starting the interview. The anonymity of the respondents is assured.

\section{Results}

Out of the total 200 residents, 151 responded to the survey. As shown in Table 1 most of the respondents were between the age group of 70 and 79, female, Chinese, Taoist and single. Most of them either had non-formal education or the highest level of education was up to primary school. Majority of them were working as labourers previously. Most perceived that they did not have anyone that they could count on for help. However, most perceived that people do take interest in them and that it was possible to get help from fellow residents and their main source of emotional support was their relatives. Majority perceived their health to be very good and their activities of daily living were not limited due to ill health, however majority had some form of chronic illness and suffered from musculoskeletal pain in the past 12 months. The mean Barthel, BMI, AAQ and WHOQOL BREF score was 16.8 (SD 4.5), 21.5 (SD 4.5), 64.5 (SD 10.1) and 69.4 (SD 11.6) respectively. 
Table 1: Baseline profile of the respondents

\begin{tabular}{|c|c|c|}
\hline Variables & Frequency & Percentage \\
\hline \multicolumn{3}{|l|}{ Age } \\
\hline $60-69$ & 27 & 17.9 \\
\hline $70-79$ & 72 & 47.7 \\
\hline$\geq 80$ & 52 & 34.4 \\
\hline \multicolumn{3}{|l|}{ Sex } \\
\hline Female & 82 & 54.3 \\
\hline Male & 69 & 45.7 \\
\hline \multicolumn{3}{|l|}{ Race } \\
\hline Chinese & 149 & 98.7 \\
\hline Others & 2 & 1.3 \\
\hline \multicolumn{3}{|l|}{ Religion } \\
\hline Taoist & 124 & 82.1 \\
\hline Buddhist & 16 & 17.9 \\
\hline Others & 11 & 57.0 \\
\hline \multicolumn{3}{|l|}{ Marital status } \\
\hline Single & 86 & 56.9 \\
\hline Married & 38 & 25.2 \\
\hline Widow/divorce & 27 & 17.9 \\
\hline \multicolumn{3}{|l|}{ Education } \\
\hline Illiterate & 56 & 37.1 \\
\hline Non formal/primary school & 61 & 40.4 \\
\hline Secondary school/tertiary & 34 & 22.5 \\
\hline \multicolumn{3}{|l|}{ Previous occupation } \\
\hline Labourer & 59 & 39.1 \\
\hline Skilled & 42 & 27.8 \\
\hline Non skilled & 33 & 21.9 \\
\hline Housewife & 17 & 11.3 \\
\hline \multicolumn{3}{|l|}{ Next of Kin } \\
\hline Family & 73 & 48.3 \\
\hline Alone & 50 & 33.1 \\
\hline Others & 28 & 18.5 \\
\hline \multicolumn{3}{|c|}{$\begin{array}{l}\text { People that can be counted on for } \\
\text { help }\end{array}$} \\
\hline None & 97 & 64.2 \\
\hline 1 or 2 & 33 & 21.9 \\
\hline$\geq 3$ & 21 & 13.9 \\
\hline \multicolumn{3}{|l|}{ Interest taken by others } \\
\hline People take interest & 65 & 43.0 \\
\hline Uncertain & 68 & 45.0 \\
\hline Little or None & 18 & 12.0 \\
\hline \multicolumn{3}{|c|}{$\begin{array}{l}\text { Feasibility of getting practical help } \\
\text { from fellow residents }\end{array}$} \\
\hline Easy & 37 & 24.5 \\
\hline Possible & 106 & 70.2 \\
\hline Difficult & 8 & 5.3 \\
\hline Main source of emotional sup & & \\
\hline
\end{tabular}

Contd...

\begin{tabular}{|c|c|c|}
\hline \multicolumn{3}{|l|}{ Table 1: Contd... } \\
\hline Variables & Frequency & Percentage \\
\hline Relatives & 54 & 35.8 \\
\hline No one & 45 & 29.8 \\
\hline Friends & 43 & 28.5 \\
\hline Spouse & 5 & 3.3 \\
\hline Staff at institution & 4 & 2.6 \\
\hline \multicolumn{3}{|c|}{ Daily activity limited due to ill health } \\
\hline Yes & 52 & 34.4 \\
\hline No & 99 & 65.6 \\
\hline \multicolumn{3}{|l|}{ Self-perception of health } \\
\hline Excellent & 17 & 11.3 \\
\hline Very good & 54 & 35.8 \\
\hline Good & 47 & 31.1 \\
\hline Fair & 28 & 18.5 \\
\hline Poor & 5 & 3.3 \\
\hline \multicolumn{3}{|l|}{ Chronic illness } \\
\hline Yes & 94 & 37.7 \\
\hline No & 57 & 62.3 \\
\hline \multicolumn{3}{|c|}{ Musculoskeletal pain past 12 months } \\
\hline Yes & 100 & 33.8 \\
\hline No & 51 & 66.2 \\
\hline \multicolumn{3}{|l|}{ Activities of daily living } \\
\hline Mean score (SD) & $16.8(4.5)$ & \\
\hline Independent & 114 & 75.5 \\
\hline Needs minimal help & 22 & 14.6 \\
\hline Dependent & 15 & 9.9 \\
\hline \multicolumn{3}{|l|}{ BMI } \\
\hline Total Score - Mean (SD) & $21.5(4.5)$ & \\
\hline Under nutrition & 43 & 28.5 \\
\hline Normal & 80 & 53.0 \\
\hline Overweight & 21 & 13.9 \\
\hline Obese & 7 & 4.6 \\
\hline \multicolumn{3}{|l|}{ Attitudes on ageing } \\
\hline Mean (SD) & $64.5(10.1)$ & \\
\hline \multicolumn{3}{|l|}{ Quality of life } \\
\hline WHO QOL BREF Mean (SD) & $69.4(11.6)$ & \\
\hline
\end{tabular}

The PSQI score ranged from 0 to 16 with a mean score of 7.1 (SD 3.4). Majority $(76.8 \%, n=116)$ of the residents had high sleep quality index $(\geq 5)$ indicating poor sleep quality as shown in Table 2.

As shown in Table 3, the mean PSQI score of those with chronic illness was higher than those without chronic illness. This difference was statistically significant. The difference in the mean scores of people that could be counted on for help and the feasibility of getting practical help from fellow residents were also statistically significant. Post hoc test 
Table 2: Base line Pittsburgh Sleep Quality Index score

\begin{tabular}{|c|c|}
\hline$\overline{P S Q I}$ & Score \\
\hline \multicolumn{2}{|l|}{ Total PSQI score } \\
\hline Minimum & 0 \\
\hline Maximum & 16 \\
\hline Mean (SD) & $7.1(3.4$ \\
\hline PSQI score<5-n (\%) & $35(23.2$ \\
\hline PSQI score $\geq 5-n(\%)$ & $116(76.8$ \\
\hline \multicolumn{2}{|c|}{ Component 1: Subjective sleep quality } \\
\hline Minimum & 0 \\
\hline Maximum & 3 \\
\hline Mean (SD) & $1.1(0.8$ \\
\hline \multicolumn{2}{|c|}{ Component 2: Sleep Latency } \\
\hline Minimum & 0 \\
\hline Maximum & 3 \\
\hline Mean (SD) & $1.9(1.0$ \\
\hline \multicolumn{2}{|c|}{ Component 3: Sleep duration } \\
\hline Minimum & 0 \\
\hline Maximum & 3 \\
\hline Mean (SD) & $1.4(1.2$ \\
\hline \multicolumn{2}{|c|}{ Component 4: Habitual sleep efficiency } \\
\hline Minimum & 0 \\
\hline Maximum & 3 \\
\hline Mean (SD) & $1.1(1.2$ \\
\hline \multicolumn{2}{|c|}{ Component 5: Sleep disturbances } \\
\hline Minimum & 0 \\
\hline Maximum & 2 \\
\hline Mean (SD) & $1.1(0.4$ \\
\hline \multicolumn{2}{|c|}{ Component 6: Use of sleeping medication } \\
\hline Minimum & 0 \\
\hline Maximum & 1 \\
\hline Mean (SD) & $0.02(0.1$ \\
\hline \multicolumn{2}{|c|}{ Component 7: Day time dysfunction } \\
\hline Minimum & 0 \\
\hline Maximum & 2 \\
\hline Mean (SD) & $0.5(0.6$ \\
\hline
\end{tabular}

showed that the mean score of respondents who perceived that they had no one to count on for help was higher than the mean score of those who perceived they have 1 or 2 persons they could count on help. And those who perceived it was difficult to get practical help from fellow residents had higher PSQI scores than those who perceived it was easier.

Table 4 shows the mean differences for the variables; people that could be counted for help, feasibility of getting help from fellow residents and chronic illness status to the seven components of the PSQI score. It can be seen here that the mean score for sleep duration and habitual sleep efficiency
Table 3: Comparison of mean Pittsburgh Sleep Quality Index scores of different variables

\begin{tabular}{|c|c|c|c|}
\hline Variables & $\begin{array}{c}\text { Global } \\
\text { PSQI score } \\
\text { mean (SD) }\end{array}$ & $\begin{array}{l}t \text { test or } \\
\text { ANOVA } \\
\text { (F)/P value }\end{array}$ & Post hoc \\
\hline \multicolumn{4}{|l|}{ Age } \\
\hline $60-69$ & $6.69(3.89)$ & $0.76 / 0.47$ & \\
\hline $70-79$ & $6.95(3.12)$ & & \\
\hline$\geq 80$ & $7.61(3.61)$ & & \\
\hline \multicolumn{4}{|l|}{ Sex } \\
\hline Female & $7.05(3.27)$ & $0.68 / 0.95$ & \\
\hline Male & $7.09(3.66)$ & & \\
\hline \multicolumn{4}{|l|}{ Race } \\
\hline Chinese & $7.03(3.41)$ & $-1.213 / 0.23$ & \\
\hline Others & $10.0(7.07)$ & & \\
\hline \multicolumn{4}{|l|}{ Religion } \\
\hline Taoist & $7.18(3.23)$ & $0.68 / 0.51$ & \\
\hline Buddhist & $7.00(4.02)$ & & \\
\hline Others & $5.91(3.45)$ & & \\
\hline \multicolumn{4}{|l|}{ Marital status } \\
\hline Single & $6.83(3.42)$ & $2.39 / 0.09$ & \\
\hline Married & $8.08(3.61)$ & & \\
\hline Widow/divorce & $6.41(3.10)$ & & \\
\hline \multicolumn{4}{|l|}{ Education } \\
\hline Illiterate & $7.70(3.04)$ & $1.502 / 0.23$ & \\
\hline $\begin{array}{l}\text { Non formal/primary } \\
\text { school }\end{array}$ & $6.72(3.28)$ & & \\
\hline $\begin{array}{l}\text { Secondary school/ } \\
\text { tertiary }\end{array}$ & $6.65(4.25)$ & & \\
\hline \multicolumn{4}{|l|}{ Previous occupation } \\
\hline Labourer & $7.12(3.07)$ & $2.61 / 0.054$ & \\
\hline Skilled & $7.95(3.83)$ & & \\
\hline Non skilled & $5.76(3.25)$ & & \\
\hline Housewife & $7.24(3.48)$ & & \\
\hline \multicolumn{4}{|l|}{ Next of Kin } \\
\hline Family & $7.58(3.84)$ & $1.55 / 0.22$ & \\
\hline Alone & $6.60(2.74)$ & & \\
\hline Others & $6.57(3.43)$ & & \\
\hline
\end{tabular}

People that can be counted on for help

None
1 or 2
$\geq 3$
$7.63(3.47) \quad 4.09 / 0.019 \quad$ None $>1$ or
$5.76(3.15)$
2

6.52 (3.29)

Feasibility of getting practical help from fellow residents

$\begin{array}{llll}\text { Easy } & 6.03(2.97) & 4.41 / 0.014 \quad \text { Difficult>Easy } \\ \text { Possible } & 7.23(3.47) & \\ \text { Difficult } & 9.75(3.85) & \end{array}$

Main source of emotional support 


\begin{tabular}{|c|c|c|c|}
\hline \multicolumn{4}{|l|}{ Table 3: Contd... } \\
\hline Variables & $\begin{array}{c}\text { Global } \\
\text { PSQI score } \\
\text { mean (SD) }\end{array}$ & $\begin{array}{l}\mathrm{t} \text { test or } \\
\text { ANOVA } \\
\text { (F)/P value }\end{array}$ & Post hoc \\
\hline Relatives & $7.37(3.37)$ & $1.38 / 0.24$ & \\
\hline No one & $7.36(3.45)$ & & \\
\hline Friends & $6.21(3.43)$ & & \\
\hline Spouse & $6.60(1.95)$ & & \\
\hline Staff at institution & $9.50(5.26)$ & & \\
\hline \multicolumn{4}{|l|}{$\begin{array}{l}\text { Daily activity limited } \\
\text { due to ill health }\end{array}$} \\
\hline Yes & $7.13(3.08)$ & $-0.22 / 0.83$ & \\
\hline No & $7.01(3.73)$ & & \\
\hline $\begin{array}{l}\text { Self-perception of } \\
\text { health }\end{array}$ & $6.00(3.10)$ & $0.58 / 0.68$ & \\
\hline \multicolumn{4}{|l|}{ Excellent } \\
\hline Very good & $6.94(3.18)$ & & \\
\hline Good & $7.38(3.56)$ & & \\
\hline Fair & $7.39(4.12)$ & & \\
\hline Poor & $7.20(2.39)$ & & \\
\hline \multicolumn{4}{|l|}{ Chronic Illness } \\
\hline Yes & $7.51(3.53)$ & $-2.06 / 0.04$ & \\
\hline No & $6.33(3.22)$ & & \\
\hline \multicolumn{4}{|l|}{ Activities of daily living } \\
\hline Independent & 7.05 (3.49) & $0.138 / 0.87$ & \\
\hline Needs minimal help & $6.86(4.04)$ & & \\
\hline Dependent & $7.47(3.45)$ & & \\
\hline \multicolumn{4}{|l|}{ BMI } \\
\hline Under nutrition & 7.05 (3.68) & $0.39 / 0.76$ & \\
\hline Normal & $6.90(3.24)$ & & \\
\hline Overweight & $7.81(3.60)$ & & \\
\hline Obese & $6.86(4.38)$ & & \\
\hline \multicolumn{4}{|l|}{$\begin{array}{l}\text { Musculoskeletal pain } \\
\text { past } 12 \text { months }\end{array}$} \\
\hline Yes & $7.29(3.28)$ & $-1.12 / 0.27$ & \\
\hline No & $6.63(3.76)$ & & \\
\hline
\end{tabular}

of those who perceived that no one could be counted for help was higher than that of those who perceived 1 or 2 persons could be counted for help. The mean score for habitual sleep efficiency of those who perceived it was difficult and those who perceived it was possible to get help from fellow residents was higher than those who perceived it was easy.

There was a negative correlation between the PSQI score and WHOQOL-BREF score $(-0.318 / 0.00)$ and the AAQ score $(-0.332 / 0.00)$. A linear regression was attempted to determine the significant predictive variables which were associated with the PSQI scores. The model in Table 5 shows that $19.7 \%\left(R^{2} 0.197\right)$ variability in the PSQI score was explained by the variables in the model. It can be seen that WHOQOL-BREF score and AAQ score are inversely associated to the PSQI score meaning that the quality of sleep is better as the attitude towards ageing and the quality of life of the respondents are positive.

\section{Discussion}

The prevalence of poor sleep quality among these residents was high and the factors associated with it was poor social relationship reflected by the complaints of difficulty in getting help from fellow residents and fewer people that could be counted on for help. Presence of chronic illness was another factor associated with poor sleep quality index.

Decreased quality of sleep may cause a decreased sense of well-being, increased risk of accidents and increased morbidity and mortality rates. ${ }^{[5-7]}$ Population study has shown that approximately $10 \%$ of the general population have insomnia and this prevalence of insomnia rises with age. ${ }^{[15]}$ It has been reported that $50 \%$ of elderly suffer sleep disorder and women ages 80-89 have the highest prevalence rates. ${ }^{[16,17]}$ In a survey conducted by the National Sleep Foundation on older adults aged 55 to 84 found that about two thirds of the participants had complained of one or more symptoms of sleep problems at least a few nights a week. ${ }^{[18]}$ Study among elderly in community dwelling in Australia found $28 \%$ had difficulty falling asleep and $42 \%$ had difficulty falling asleep and maintaining sleep. ${ }^{[19]}$ In residential care centres the prevalence of sleep disorders have been reported from $44.4 \%$ in Iran, ${ }^{[20]} 45 \%$ in USA ${ }^{[21]}$ to $69.3 \%$ in Taiwan ${ }^{[22]}$ which are lower than the $76.8 \%$ reported in the present study.

Poor social relationship as evident by the number of people that could be counted for help and the feasibility of getting help was another factor which was associated with poor sleep quality in this study. This is not surprising considering social relationships have been linked with sleep quality. ${ }^{[23]}$ Most elderly Asian expect family centred care, however due to the change in family structure, loss of spouse and inability to care for self has led some elders to be institutionalized. [24] The new experience of living in an institution may lead to the feeling of isolation compounded by the possible grief may potentiate insomnia in the elderly. ${ }^{[25]}$ In Taiwan many older adults in institutional care feel that their families have abandoned them. ${ }^{[26]}$ To make matters worse people with sleep problem seldom share their experiences with others because they believe that sleep problems are personal and a private matter making them feel lonely and helpless.

The poor quality of sleep affects one's health and psychosocial well-being. Because social relationships affect 
Table 4: Comparison of the mean of the different components of the Pittsburgh Sleep Quality Index score with significant variables

\begin{tabular}{|c|c|c|c|c|c|c|c|c|c|}
\hline \multirow[t]{2}{*}{$\begin{array}{l}\text { PSQI } \\
\text { components }\end{array}$} & \multicolumn{3}{|c|}{$\begin{array}{l}\text { People that can be counted on for } \\
\text { help mean (SD) }\end{array}$} & \multicolumn{3}{|c|}{$\begin{array}{l}\text { Feasibility of getting help from fellow } \\
\text { residents mean (SD) }\end{array}$} & \multicolumn{2}{|c|}{$\begin{array}{l}\text { Chronic illness mean } \\
\text { (SD) }\end{array}$} & \multirow[t]{2}{*}{ Post hoc } \\
\hline & None & 1 or 2 & $\geq 3$ & Easy & Possible & Difficult & No & Yes & \\
\hline $\begin{array}{l}\text { Subjective } \\
\text { sleep quality }\end{array}$ & $1.09(0.81)$ & $0.88(0.65)$ & $0.81(0.60)$ & $0.84(0.55)$ & $1.03(0.79)$ & $1.50(0.93)$ & $0.84(0.75)^{\#}$ & $1.11(0.74)^{\#}$ & \\
\hline Sleep Latency & $1.98(0.98)$ & $1.70(1.10)$ & $1.95(1.02)$ & $1.84(1.07)$ & $1.88(1.00)$ & $2.75(0.46)$ & $1.93(0.98)$ & $1.90(1.03)$ & \\
\hline Sleep duration & $1.61(1.19)^{*}$ & $0.94(1.12)^{*}$ & $1.29(1.10)^{*}$ & $1.16(1.07)$ & $1.48(1.19)$ & $1.75(1.49)$ & $1.19(1.17)$ & $1.55(1.18)$ & None $>1$ or 2 \\
\hline \multirow{3}{*}{$\begin{array}{l}\text { Habitual sleep } \\
\text { efficiency }\end{array}$} & $1.34(1.18)^{\star \star}$ & $0.64(0.96)^{\star \star}$ & $0.90(1.26)^{* *}$ & $0.62(0.98)^{\star \star *}$ & $1.25(1.17)^{\star \star \star}$ & $1.88(1.55)^{\star \star \star}$ & $0.86(1.16)^{\# \#}$ & $1.29(1.18)^{\# \#}$ & None $>1$ or 2 \\
\hline & & & & & & & & & Possible>easy \\
\hline & & & & & & & & & Difficult>easy \\
\hline $\begin{array}{l}\text { Sleep } \\
\text { disturbances }\end{array}$ & $1.14(0.41)$ & $1.12(0.33)$ & $0.95(0.38)$ & $1.05(0.33)$ & $1.14(0.40)$ & $1.00(0.54)$ & $1.05(0.35)$ & $1.15(0.41)$ & \\
\hline $\begin{array}{l}\text { Use of sleeping } \\
\text { medication }\end{array}$ & $0.02(0.14)$ & $0.00(0.00)$ & $0.05(0.22)$ & $0.03(0.16)$ & $0.01(0.09)$ & $0.13(0.354)$ & $0.02(0.13)$ & $0.02(0.15)$ & \\
\hline $\begin{array}{l}\text { Day time } \\
\text { dysfunction }\end{array}$ & $0.44(0.63)$ & $0.51(0.09)$ & $0.57(0.68)$ & $0.49(0.61)$ & $0.44(0.62)$ & $0.75(0.45)$ & $0.44(0.57)$ & $0.49(0.64)$ & \\
\hline
\end{tabular}

Table 5: Linear regression

\begin{tabular}{lcccc}
\hline & B & $t$ & Sig & $95 \% \mathrm{Cl}$ \\
\hline${ }^{*}$ QOL score & -0.063 & -2.503 & 0.013 & $-0.113 ;-0.013$ \\
${ }^{*}$ Attitude to ageing & -0.053 & -2.653 & 0.009 & $-0.092 ;-0.013$ \\
ADL score & 0.91 & 1.478 & 0.142 & $-0.031 ; 0.213$ \\
BMI score & 0.015 & 0.253 & 0.801 & $-0.100 ; 0.130$ \\
$\begin{array}{l}\text { People who are close } \\
\text { that can be counted on }\end{array}$ & -0.117 & -0.282 & 0.779 & $-0.941 ; 0.706$ \\
$\begin{array}{l}\text { Feasibility to get help } \\
\text { from fellow residents }\end{array}$ & 0.878 & 1.519 & 0.131 & $-0.265 ; 2.020$ \\
Chronic illness & 0.929 & 1.697 & 0.092 & $-0.153 ; 2.011$ \\
\hline${ }^{*}$ significant & & & &
\end{tabular}

the quality of life $e^{[27]}$ it was expected to find a correlation between quality of life and quality of sleep. Numerous studies have shown that poor sleep quality adversely affect the quality of life. ${ }^{[28-31]}$ Environment is an important component of the WHOQOL-BREF. Environment is strongly associated with quality of life in respect to social interaction, activity involvement, independence and psychological wellbeing. ${ }^{[32,33]}$ Studies among the Thai and Myanmar older adults have shown that poor social relationship, chronic illness and sleep difficulty to be associated with poor quality of life. ${ }^{[34,35]}$

Attitude, perception and belief of the elderly towards themselves affect the sleep quality of the elderly. The AAQ scale also has psychosocial component which take into account close relationships with members of the community and involvement in activities. In a study conducted in Japan to determine the relationship between sleep disturbance and morale in elderly people found that sleep disturbance to be related to negative attitude towards own aging. ${ }^{[36]}$
Studies have shown that sleep efficiency is affected by age related medical and psychiatric illnesses. ${ }^{[19,37]}$ Many older adults suffer from one or more chronic medical conditions that can contribute to sleep difficulties. ${ }^{[38]}$ In one estimate it was reported that $80 \%$ of older adults suffer at least a chronic disorder which makes them susceptible to sleep disorders. ${ }^{\left[{ }^{[9]}\right.}$ In a study conducted by the National Institute of Health in Malaysia, $81.4 \%$ of the older adults had at least one chronic illness and $12.7 \%$ had at least three or more chronic illnesses. ${ }^{[40]}$ In a study conducted to examine the interplay of social engagement, sleep quality and plasma levels of interleukin-6, regression analysis showed that the association of age and sleep efficiency was mediated by the presence of chronic health conditions. ${ }^{[23]}$ In another study conducted in Taiwan among elderly Taiwanese aboriginal women found that chronic illness as a significant factor associated with poor sleep quality. ${ }^{[41]}$

\section{Conclusion}

The prevalence of poor quality of sleep in this study population was high. Poor social relationships and negative attitude towards ageing as evident by the inverse relationship found between the QOL and the attitude towards ageing scores were significantly associated with the PSQI scores. Administrators of the institutions of care for the aged should be made aware the importance of social interactions.

\section{ACKNOWLeDgments}

The authors would like to thank the staff and the management of the Silver Jubilee home for the elderly for all their support. 


\section{References}

1. Venne R. Mainstreaming the concerns of older persons into the social development agenda. United Nations Secretariat. Division for Social Policy and Development; 2005.

2. Zaimi AR. Social Welfare Policies And Services For The Elderly: A Country Report (Malaysia): For The $5^{\text {th }}$ ASEAN and Japan High Level Officials Meeting on Caring Societies: Collaboration of Social Welfare and Health Services, and Development of Human Resources and Community -Community Services for the Elderly. 27-90uyjh6730 August 2007, Tokyo, Japan. Available from: http://www.jicwels.or.jp/about_jicwels/ ASEAN and JapanHighLevelOfficialsMeeting/ $5^{\text {tho }}$ 20Mtg.\%20 Country $\% 20$ Report $\% 202007 \% 20$-Community $\% 20$ Services $\% 20$ for $\% 20^{\text {th }} \mathrm{e} \% 20$ Elderly-/Malaysia\%20Welfare.pdf. [Last accessed on 2012 Jan 05].

3. O'Neill PA. Caring for the older adult: A health promotion perspective. Philadelphia: W.B. Saunders Company; 2002.

4. Buysse DJ, Reynolds CF, Monk TH, Berman SR. Pittsuburgh Sleep Quality Index: A new instrument for psychiatric practice and research. Psychiatry Res 1989;28:193-213.

5. National Sleep Foundation. Sleep-awake cycle: Its physiology and impact on health. Washington DC, 2006. Available from: http://www.sleepfoundation.org/atf/cf/\%/7BF6BF2668-A1B4-4 FEB-8D1A-A5D39340D9CB\%7D/Sleep-Wake_Cycle.pdf. [Last accessed on 2011 Jan 12].

6. Knutson KL. Role of sleep duration and quality in the risk and severity of type 2 diabetes Mellitus. Arch Intern Med 2006;166:1768-74.

7. Flaherty JH. Insomnia among hospitalized older adults. Clin Geriatr Med 2008;24:51-67.

8. Nicholl C, Wilson KJ, Webster S. Elderly care medicine. $7^{\text {th }}$ ed. Oxford UK: Blackwell Publishing; 2008.

9. Krystal AD. Insomnia in women. Clin Cornerstone 2003;5:41-50.

10. Zhang B, Wing YK. Sex difference in insomnia: A meta-analysis. Sleep 2006;29:85-93.

11. Stoller MK. Economic effects of insomnia. Clin Ther 1994;16:873-97.

12. Hellstrom A, Hagell P, Fagerstrom C, Willman A. Measurement properties of the Minimal Insomnia Symptom Scale (MISS) in an elderly population in Sweden. BMC Geriatr 2010;10:84

13. World Health Organization. WHOQOL - BREF introduction, administration, scoring and generic version of the assessment. Geneva: Programme on mental Health; 1996.

14. Laidlaw K, Power MJ, Schimdt S. The WHOQOL-OLD group. The attitudes to ageing questionnaire (AAQ): Development and psychometric properties. Int J Geriatr Psychiatry 2007;22:367-79.

15. Ford DE, Kamerow DB. Epidemiologic study of sleep disturbances and psychiatric disorders. An opportunity for prevention? JAMA 1989;262:1479-84.

16. Shives LR. Basic Concepts of Psychiatric-Mental Health Nursing. $6^{\text {th }}$ ed. Philadelphia: Lippincott Williams and Wilkins; 2004.

17. Lichstein KL. Insomnia in the elderly. Sleep Med Clin 2006;1:221-9.

18. National Sleep Foundation. Sleep in America poll. Washington DC. Available from: http://www.kintera.org/arf/cf/\%7BF6BF266 8-A1B4-4FEB-8D1A-A5D39340D9CB\%7D/2003SleepPollExecSu mm.pdf. [Last accessed on 2011 Jan 12].

19. Foley DJ, Monjan A, Brown SL, Simonsick E, Wallace R, Blazer D. Sleep complaints among elderly persons: An epidemiological study of three communities. Sleep 1995;18:425-32.

20. Hosseini H, Esfirizi MF, Marandi SM, Rezaei A. The effect of Tai Chi exercise on the sleep quality of the elderly residents in Isfahan, Sadeghieh elderly home. Iran J Nurs Midwifery Res 2011;16:55-60.

21. Cohen D, Eisdorfer C, Prinz P, Breen A, Davis M, Gadsby A. Sleep disturbances in institutionalized age. J Am Geriatr Soc 1983;32:79-82.

22. Lin CL, Su TP, Chang M. Quality of sleep its associated factors in the institutionalized elderly. Formosan J Med 2003;7:174-84.

23. Friedman EM, Hayney MS, Love GD, Urry HL, Rosenkranz MA, Davidson RJ, et al. Social relationships, sleep quality and interleukin-6 in aging women. Proc Natl Acad Sci U S A 2005; 102:18757-62.

24. Liu YW, Chuang HM. Investigation of the decision making procession of how disable elders' families choose long term care welfare services. Soochow J Soc Work 2006;14:91-123.

25. Ancoli-Israel S. All I want is a Good Night's. Chicago, IL: Mosby -Year Book Inc.; 1996.

26. Chen KM, Chen MH, Lin MH, Fan JT, Lin HS, Li CH. Effects of Yoga sleep quality and depression in elders in assisted living facilities. J Nurs Res 2010;18:53-61.

27. Mudey A, Ambekar S, Goyal RC, Agarekar S, Wagh VV. Assessment of Quality of Life among rural and urban elderly population of Wardha district, Maharashtra, India. Ethno Med 2011;5:89-93.

28. Newman AB, Nieto FJ, Guidry U, Lind BK, Redline S, Pickering TG, et al. Relation of sleep disordered breathing to cardiovascular disease risk factors: The sleep heart health study. Am J Epidemiol 2001;154:50-9.

29. Shahar E, Whitney CW, Redline S, Lee T, Newman AB, Javier Nieto F, et al. Sleep disordered breathing and cardiovascular disease: A cross sectional results of the sleep heart health study. Am J Respir Crit Care Med 2001;163:19-25.

30. Baldwin CM, Ervin A-M, Mays MZ, Robbins J, Shafazand S, Walsleben J, et al. Sleep disturbances, quality of life and ethnicity: The sleep heart health study. J Clin Sleep Med 2010;6:176-83.

31. Faubel R, Lopez-Garcia E, Guallar-Castillon P, Balboa-Castillo T, Gutierrez-Fisac J, Banegas JR, et al. Sleep duration and health related quality of life among older adults: A population based cohort in Spain. Sleep 2009;32:1059-68.

32. Hwang HF, Liang WM, Chiu YN, Lin MR. Suitability of the WHOQOL-BREF for the community-dwelling older people in Taiwan. Age Ageing 2003;32;593-600.

33. Lawton MP. The physical environment of the person with Alzheimer's disease. Aging Ment Health 2001;S1:S56-64.

34. Assantachai P, Maranetra N. Nationwide survey of the health status and quality of life of elderly Thais attending clubs for the elderly. J Med Assoc Thai 2003;86:938-46.

35. Naing MM, Nanthamongkolchai S, Munsawaengsub C. Quality of life of the elderly people in Einne Township Irrawaddy Division, Myanmar. ASIAPH 2010;1:4-10.

36. Ichimiya $A$, Iqata $R$, Ogomori $K$, Iqata $T$. The relationship between sleep disturbance and morale in Japanese elderly people. Int Psychogeriatr 2005;17:443-9.

37. Kryger M, Monjan A, Bliwise D, Ancoli-Israel S. Sleep, health and ageing. Bridging the gap between science and clinical practice. Geriatrics 2004;59:24-30.

38. Ancoli-Israel S, Cooke JR. Prevalence and comorbidity of insomnia and effect on functioning in elderly population. J Am Geriatr Soc 2005;53:1299-304. 
39. Mauk KL. Gerontological Nursing: Competencies of Care. Massachusetts: Jones and Bartlett Publishers; 2006.

40. Chua SL. 2006. Statistics Given in speech by Minister of Health Malaysia, at the Asia Pacific Geriatric Conference. $7^{\text {th }}$ April 2006. Available from: http://www.moh.gov.my/Mohportal/ Downloadservlet?id=701 and type 2. [Last accessed on 2006 Jan 22].

41. Chueh KH, Yang MS, Chen CS, Chiou SM. Poor sleep quality and alcohol use problems among elderly Taiwanese aboriginal women. Int Psychogeriatr 2009;21:593-9.

How to cite this article: Rashid A, Ong EK, Wong ESY. Sleep quality among residents of an old folk's home in Malaysia. Iranian J Nursing Midwifery Res 2012;17:512-9.

Source of Support: None, Conflict of Interest: None. 